\title{
Lichen Trimlines in the Peace-Athabasca Delta: Variations in Flora, Form, and Disturbance Regime
}

\author{
KeVin P. TimoneY ${ }^{1}$ and JANET MarSH ${ }^{2}$ \\ ${ }^{1}$ Treeline Ecological Research, 21551 Twp Road 520, Sherwood Park, Alberta, T8E 1E3 Canada; e-mail: ktimoney@ compu \\ smart.ab.ca \\ ${ }^{2} 9407^{\text {th }}$ Avenue NE, Calgary, Alberta, T2E 0N8 Canada; e-mail: Marshj4@aol.com
}

Timoney, Kevin P., and Janet Marsh. 2005. Lichen trimlines in the Peace-Athabasca Delta: variations in flora, form, and disturbance regime. Canadian Field-Naturalist 119(1): 76-81.

Lichen trimlines are characteristic of aquatic systems where lichen-covered rocks border fluctuating water bodies. This study examined water-origin saxicolous lichen trimlines on acidic metacrystalline bedrock outcrops in the Peace-Athabasca Delta, northern Alberta, Canada. Twenty-seven species of saxicolous lichens were found in the vicinity of the trimlines. Species richness above the trimline ( 26 species) was almost twice that found below the trimline ( 14 species). Colonization lag time, differences in susceptibility to disturbance, and site influences on lichen establishment and survival might be involved in the absence of many species below trimlines. In frequently inundated areas, rock surfaces are dominated by the amphibious lichens Staurothele fissa and S. drummondii. The dominant lichen colonizer below trimlines was Physcia caesia. Other important colonizers below trimlines included Phaeophyscia sciastra and Physcia dubia, and on rocks fertilized by bird feces, Xanthoria elegans. A curious feature of the saxicolous flora was the presence of many calciphiles. Variations in trimline form and height and constituent species are related to the hydrologic and disturbance regime. Trimlines in perched basins tend to be near current water level, horizontal, and distinct, and indicate a relatively stable, infrequently flooded environment. Trimlines at open-drainage sites tend to be high above current water, wavy, and indistinct, and indicate a strongly-pulsed environment with frequent disturbances. Those at restricted-drainage basins are variable in form and height and disturbance regime.

Key Words: delta, disturbance, Peace-Athabasca, saxicols, trimline, water regime, wetland, zonation, Alberta.

Zonation of lichen communities along lake and river shores has been noted for many decades (e.g., Santesson 1939) and has been attributed to gradients in physical and ecological factors. Lichen species differ in their tolerance of immersion/desiccation, siltation, water and substrate chemistry, water and ice scouring, current velocity, substrate stability, wave splash, shade, competition with bryophytes and vascular plants, and colonization rates after disturbance (Scott 1967; Ried 1974; Rosentreter 1984; Beckelhimer and Weaks 1984, 1986; Pereira et al. 1987; Gilbert and Giavarini 1997, 2000). While naming conventions have differed, lichenologists have consistently noted four lichen zones along lakes and rivers; e.g., for British lakes, Gilbert and Giavarini (2000) used the zones "terrestrial", "upper splash", "lower splash", and "submerged", while for the lower reaches of the Salmon River, Idaho, USA, Rosentreter (1984) used the zones "extreme flood", "high flood", "normal flood", and "low water".

Saxicolous lichen trimlines are typically distinct transition zones on bedrock-lined shores, below which lichens intolerant of immersion may be scarce or absent (Timoney and Marsh 2004). Above the line, there may be a continuous lichen flora attached to the rock surface; below the line there may be dominance by amphibious lichens such as Verrucaria or Staurothele (Brodo et al. 2001). In terms of typical lichen zonation, a trimline would be located somewhere in the "upper splash" / "high flood" zone.
Worldwide, there are two fundamentally different types of lichen trimlines: those due to scouring by glacial ice and those due to aquatic disturbances (e.g., Winchester and Harrison 2000). The latter are typically due to flooding or sedimentation that results in lichen mortality, followed by a low water period that exposes the transition between living lichens and bare rock or tree bark (Hale 1984; Beckelhimer and Weaks 1984, 1986).

Saxicolous lichen trimlines are characteristic of aquatic systems where lichen-covered rocks border fluctuating water bodies, e.g., in Florida (Hale 1984), in the Geraldine Lakes area of Jasper National Park, Alberta, and at various lakes in the Boundary Waters Canoe Area, Minnesota, USA (Timoney, field observations), in New South Wales, Australia (Gregory 1976), and on Georgian Bay, Ontario (Mitchell 2002).

In this era of generally declining water levels in much of North America, lichen trimlines may be useful as datable markers of previous high water levels. The objectives of this note are to document the lichen species growing on rock near lichen trimlines in a strongly-pulsed northern wetland and to describe variations in trimline form in the context of ecological and hydrological factors.

\section{Study Area}

The study area is located in the northeast portion of the Peace-Athabasca Delta, northern Alberta. While 
the delta is located within the Continental High Boreal wetland region of Canada (National Wetlands Working Group 1988), its biota and vegetation are characteristic of the Continental Prairie wetland region (Timoney 2002). Inclusive of Point Providence and the Scow Channel areas, the total area of the delta is $5168 \mathrm{~km}^{2}$, composed of $2406 \mathrm{~km}^{2}$ of water and 2762 $\mathrm{km}^{2}$ of non-water. The non-water portion of the delta includes forests, shrublands, marshes, meadows, mudflats, peatlands, and bedrock knolls. The present, dominant non-aquatic vegetation of the delta includes Carex atherodes (Awned Sedge) and Scolochloa festucacea (Spangletop) marshes, Calamagrostis canadensis (Bluejoint Reedgrass) meadows, Salix (Willow) thickets and savannahs, and forests of Populus balsamifera (Balsam Poplar) and Picea glauca (White Spruce) (Timoney 2004*).

Drainage basins are classified as hydrologically "open" (connected to Lake Athabasca or to major rivers at all times); semi-restricted (connected only at times of high water); or perched (receiving water only during ice-jam floods, through local precipitation or by local drainage within their catchments). Bedrock outcrops border many of these basins and are composed primarily of Precambrian acidic metacrystalline rocks (granitic or felsic gneisses). Many of these bedrock outcrops exhibit saxicolous lichen trimlines.

\section{Methods}

Sixteen sites that represented three basin types (open, semi-restricted, and perched) were sampled from 17-21 June 2002 and from 25-29 August 2003 (Table 1, Figure 1) as part of a reconstruction of water levels by lichenometry (Marsh and Timoney 2003). Access to the sites was by boat or helicopter (Site 5 is accessible on foot). Each site consisted of a boulder outcrop that exhibited a lichen trimline. At each site,

TABLE 1. Location (decimalized latitude and longitude) and basin type of the trimline study sites.

\begin{tabular}{rlll}
\hline \hline Site & Latitude & Longitude & Basin Type \\
\hline 1 & 58.497 & 119.593 & open \\
2 & 58.546 & 119.605 & perched \\
3 & 58.532 & 119.601 & semi-restricted \\
4 & 58.342 & 119.555 & semi-restricted \\
5 & 58.420 & 119.574 & open \\
6 & 58.408 & 119.571 & open \\
7 & 58.497 & 119.593 & open \\
8 & 58.522 & 119.599 & perched \\
9 & 58.558 & 119.608 & perched \\
10 & 58.577 & 119.613 & semi-restricted \\
11 & 58.610 & 119.621 & perched \\
12 & 58.608 & 119.620 & perched \\
13 & 58.666 & 119.635 & perched \\
14 & 58.658 & 119.633 & semi-restricted \\
15 & 58.518 & 119.598 & perched \\
$*$ & 58.521 & 119.599 & semi-restricted \\
\hline \hline
\end{tabular}

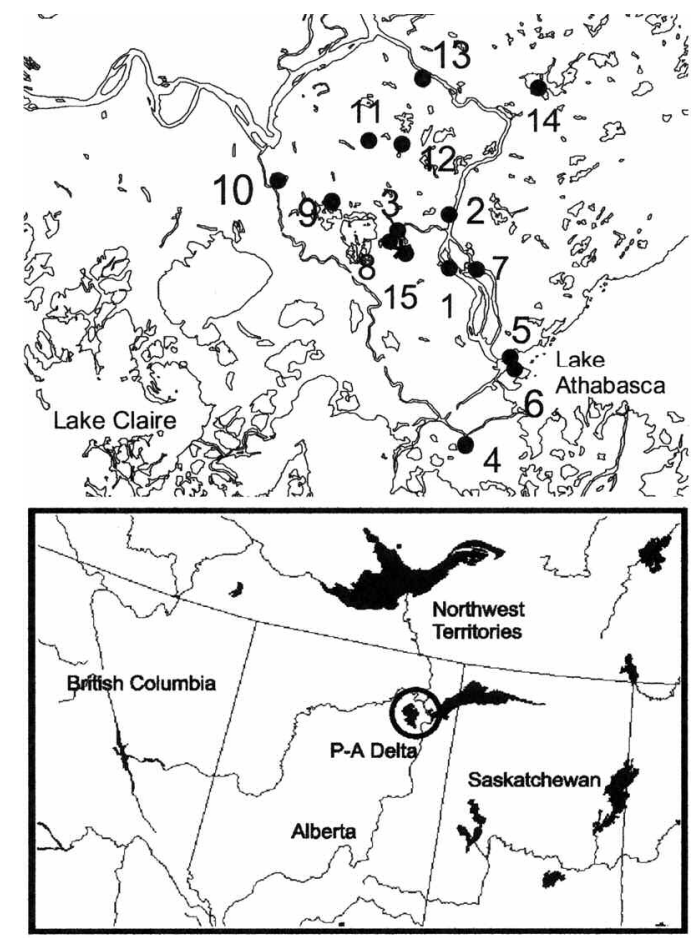

FIGURE 1. Top: Lichen study sites in the northeast sector of the Peace-Athabasca Delta (geographic center at $\left.\sim 111^{\circ} 20^{\prime} \mathrm{W}, 58^{\circ} 48^{\prime} \mathrm{N}\right)$. The asterisk * between Sites 3,8 and 15 refers to "lichen observation site". Width of image from east to west is $\sim 66 \mathrm{~km}$. Bottom: regional context of study area.

a bench mark (a galvanized nail with orange flagging) was placed on the trimline in the middle of the area that was to be surveyed. The site was plotted on an NTS 1:50000 map, from which UTM coordinates were derived. The vertical height of the lichen trimline was measured with a clinometer (used as a level) sighted on a tape measure at the water's edge. Lichen species present near the trimline were recorded or collected for later identification. Sampling focused on foliose and crustose species attached to rock below the trimline and within one vertical meter above the trimline (i.e., roughly, in the "upper splash" / "high flood" and the "terrestrial" / "extreme flood" zones). For each species, $</=15$ lichen thalli diameters were measured to the nearest $\mathrm{mm}$. The choice of thalli was not random; we looked for the larger thalli. Site descriptions of trimline aspect, width, elevation, slope, and vegetation community were prepared and photographs were taken. We described trimline form and noted relevant site and disturbance factors. Lichen nomenclature follows Esslinger $\left(1997^{*}\right)$, and that for vascular plants follows Moss (1983). 


\section{Results \\ Flora}

The saxicolous lichen flora included at least 27 species (Table 2). Twenty-six species were found above the trimline and 14 species were found below the trimline. Only one species, Staurothele drummondii, appeared to be restricted to the zone below the trimline although Staurothele fissa was more abundant below the trimline than above it. There was a strong compositional break at the trimline. Many species common above trimlines were not found below trimlines, e.g., Aspicilia, Dimelaena, Dermatocarpon, Lasallia, and Umbilicaria and some species of Melanelia and Parmelia. Other species found above and below the trimline were far more abundant above the trimline (e.g, Xanthoparmelia somloënsis).

Below the trimline, rock surfaces were usually dominated by Staurothele drummondii or S. fissa, dark brown, thin crustose lichens with or without an assemblage of colonizing lichens such as Physcia caesia. At the majority of outcrops, the lichen community within circa one meter above the lichen trimline (the dry zone) was dominated by the foliose lichens Xanthoparmelia somloënsis, Physcia caesia, P. phaea, Phaeophyscia sciastra, Melanelia stygia, Rhizoplaca chrysoleuca, Umbilicaria deusta and the crustose lichens Rhizocarpon disporum, Dimelaena oreina and Aspicilia caesiocinerea. Beyond the reach of extreme high water, were a variety of lichen communities, e.g., fruticose mat formers (e.g., many Cladonia/Cladina species) or Umbilicaria-dominated areas, or vascular plant and moss communities (e.g., Juniperus (Juniper), Saxifraga tricuspidata (Prickly Saxifrage), Amelanchier alnifolia (Saskatoon), Agropyron trachycaulum (Slender Wheatgrass), Polytrichum, Drepanocladus, etc.) that lay beyond the scope of this study.

\section{Variations in Trimline Form, Disturbance Regime, and Flora}

Typical trimline form in open basins was wavy and indistinct; that in perched basins was level and distinct; in semi-restricted basins trimline form was variable (Table 3). Median trimline heights in open and semirestricted basins were $>2 \mathrm{~m}$ above current water levels, while perched basin trimline heights were $<1 \mathrm{~m}$ above basin water levels. Median trimline elevations were similar across types while water elevations in open and semi-restricted basins were lower than in perched basins.

We observed seven variations in the trimlines.
TABLE 2. Saxicolous lichen species observed at the 16 study sites.

\begin{tabular}{lcc}
\hline \hline Species & $\begin{array}{c}\text { Above } \\
\text { Trimline }\end{array}$ & $\begin{array}{c}\text { Below } \\
\text { Trimline }\end{array}$ \\
\hline Aspicilia caesiocinerea & $x$ & \\
Cladina stellaris & $x$ & \\
Dermatocarpon reticulatum & $x$ & \\
Dimelaena oreina & $x$ & \\
Lasallia pensylvanica & $x$ & \\
Leproloma vouauxii & $x$ & $x$ \\
Melanelia disjuncta & $x$ & \\
Melanelia sorediata & $x$ & \\
Melanelia stygia & $x$ & $x$ \\
Parmelia saxatilis & $x$ & \\
Parmelia sulcata & $x$ & \\
Phaeophyscia sciastra & $x$ & $x$ \\
Phaeophyscia hispidula & $x$ & \\
Physcia caesia & $x$ & $x$ \\
Physcia dubia & $x$ & $x$ \\
Physcia phaea & $x$ & $x$ \\
Physconia muscigena & $x$ & $x$ \\
Placidium squamulosum & $x$ & $x$ \\
Ramalina intermedia & $x$ & $x$ \\
Rhizocarpon disporum & $x$ & $x$ \\
Rhizoplaca chrysoleuca & $x$ & $x$ \\
Staurothele drummondii & & $x$ \\
Staurothele fissa & $x$ & \\
Umbilicaria deusta & $x$ & \\
Umbilicaria muehlenbergii & $x$ & \\
Xanthoparmelia somloënsis & $x$ & \\
Xanthoria elegans & $x$ & \\
\hline \hline & & \\
\hline
\end{tabular}

At Perched and Semi-Restricted Basins:

1. In most perched basins, trimlines were level and distinct with a characteristic flora of colonizing lichens below the trimline indicative of infrequent water level fluctuations (Figure 2a).

2. In two perched and semi-restricted basins, there were no colonizing lichens below a trimline located near the current standing water. The below trimline communities were dominated by amphibious Staurothele fissa and/or S. drummondii. Such sites indicate frequent small water level fluctuations. At Site 10 (Figure 2b), water levels were influenced by beavers. Dominance by lichens that favor periodic submergence and the absence of other lichens argues for periodic inundation. At Site 12, a high elevation, isolated perched basin (Figure 2c), the lowermost Staurothele was submerged $20 \mathrm{~cm}$ at time of sampling (19 June 2002).

3. At Site 11 (Figure 2d), the mid-lake outcrop served as a resting area for ducks and black terns (Chlidonias niger). Nitrophilic Xanthoria elegans and amphibious Staurothele were the only lichen species present below the trimline.

TABLE 3. Trimline form, height, elevation and water elevation by basin type.

\begin{tabular}{llccc}
\hline \hline Basin Type (n) & Trimline Form & $\begin{array}{c}\text { Trimline Ht } \\
\text { (median, m)* }\end{array}$ & $\begin{array}{c}\text { Trimline Elevation } \\
\text { (median, m asl) }\end{array}$ & $\begin{array}{c}\text { Water Elevation } \\
\text { (median, m asl) }\end{array}$ \\
\hline open (4) & wavy, indistinct & 2.20 & 210.83 & 208.61 \\
semi-restricted (5) & variable & 2.18 & 210.44 & 208.29 \\
perched (7) & level, distinct & 0.91 & 210.78 & 209.84 \\
\hline \hline
\end{tabular}

* above water level at time of sampling 

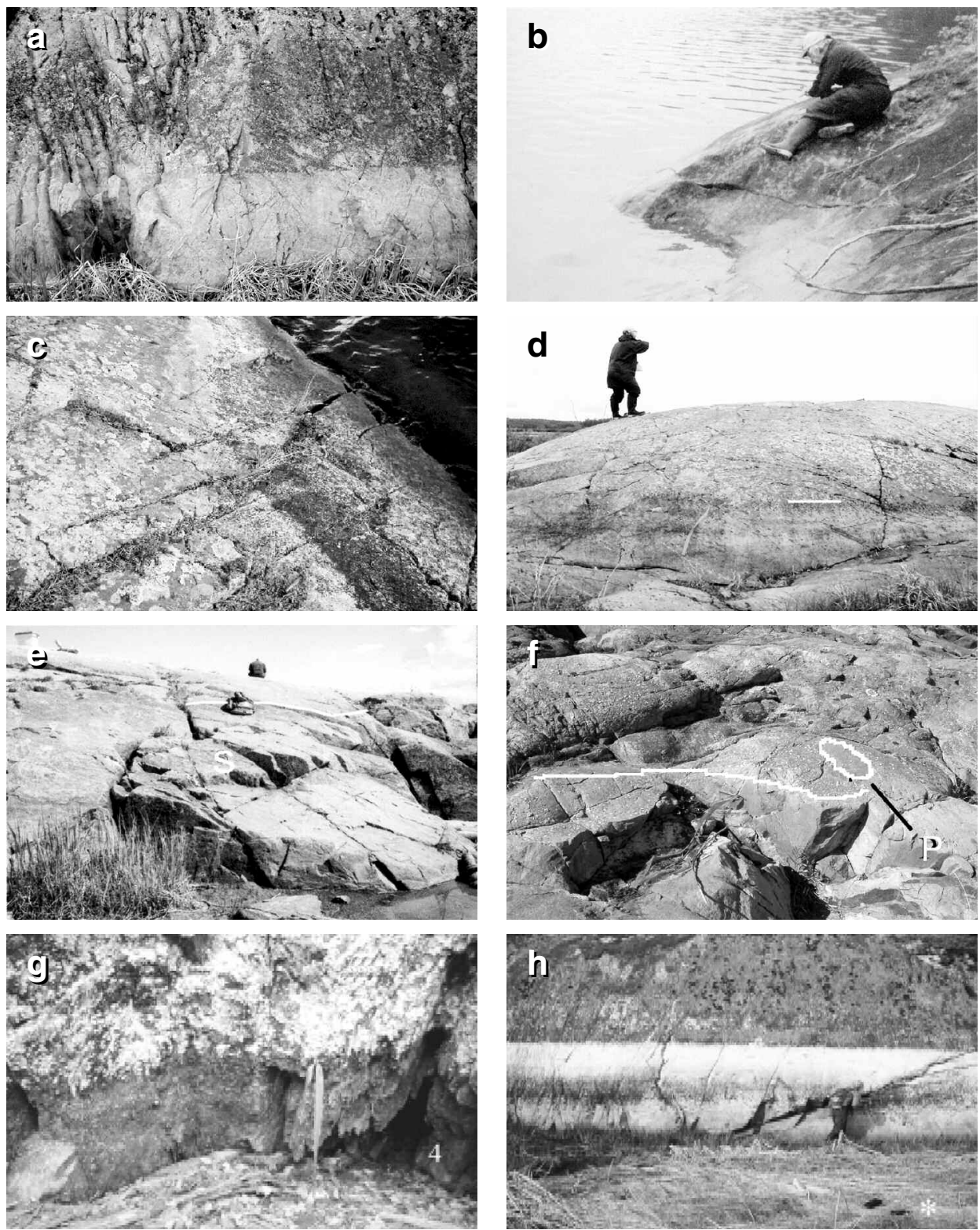

FIGURE 2(a) A distinct and level trimline at perched basin Site 2, $79 \mathrm{~cm}$ above water at time of sampling. Physcia caesia was only colonizing lichen below the trimline. (b) A Staurothele community at a beaver-dam influenced semi-restricted basin (Site 10) with a trimline $40 \mathrm{~cm}$ above water. (c) At this isolated, bedrock upland perched basin (Site 12), above the trimline (left half of photo), dominants are Rhizocarpon, Xanthoparmelia, Aspicilia, and Melanelia. At the indistinct trimline (60 $\mathrm{cm}$ above water), there is a lichen-free whitish band, followed by a blackish Staurothele band, and below that, extending under water, a mixture of oxide-staining and Staurothele thalli. (d) A level trimline influenced by bird feces at perched basin Site 11, $102 \mathrm{~cm}$ above water. Above the trimline (white line) Xanthoria elegans dominates the cover (its orange thalli do not contrast well against the bedrock in the gray scale image); Physcia caesia is the only other colonizing lichen present. The dark band below the trimline is composed of Staurothele. (e) A high, indistinct, wavy trimline (white line near the backpack) at Site 5 on Lake Athabasca, $224 \mathrm{~cm}$ above water. Dominant colonizing lichen below the trimline was Physcia caesia, accompanied by amphibious Staurothele (white S) near water level. (f) A wavy and indistinct trimline at Site 7, $220 \mathrm{~cm}$ above water, along the Rochers River. Note the patch of flaked rock (pointer from P) in which several young lichens have established. (g) A Leproloma vouauxii trimline on a moist and shady vertical to overhanging gneiss at Site 4, behind a levee, $230 \mathrm{~cm}$ above river level. (h) A high, distinct level trimline at the semi-restricted "*"site, $218 \mathrm{~cm}$ above water. Note the band of lichen-free white weathered rock below the trimline, below that the blackish Staurothele band, and the lowest band (light gray, but reddish orange in color) of iron oxide stained rock. 
Sites:

At Open (and Semi-restricted) Basins and Riparian

4. Open basins were typified by high and often indistinct and wavy trimlines (Figure 2e). Colonizing lichens were present or absent, but Staurothele was present near the current water level. The high trimlines indicated a large drawdown, while the indistinct and wavy trimlines indicated episodic inundation or disturbance by e.g., open water and ice-jam floods, seiches, and ice scour. The disturbance regime at Lake Athabasca sites would be influenced by aspect and exposure to prevailing winds, waves, and ice scour.

5. The typical active riparian trimline was high and sometimes indistinct and wavy, indicative of active disturbance. At Site 7 on the Rochers River, patches of unweathered, lichenfree rock existed alongside rock covered by large, mature lichens and patches with young, newly-establishing lichens (Figure 2f). Colonizing lichens and Staurothele spp. may be present or absent at such sites.

6. Site 4 (Figure 2g), along a semi-active branch of the Quatre Fourches River not subject to wave or ice action, was a moist, shady seepage site of vertical to overhanging beds of gneissic bedrock. There was nearly complete cover of Leproloma vouauxii above the trimline and a sparse cover below the trimline; Ramalina intermedia and Physcia caesia were present above the trimline.

7. At two semi-restricted sites, we found no colonizing lichens below a level, high, distinct trimline on weathered granite, below which only Staurothele grew (Figure $2 \mathrm{~h}$ ). The absence of non-amphibious lichens indicates an unexplained impediment to lichen colonization and/or survival. The area is subject to seiches; e.g., from evening 18 June to evening 19 June 2002, local water level fell $30 \mathrm{~cm}$. But seiches of a $2 \mathrm{~m}$ magnitude would be difficult to envision and would not be of sufficient duration to kill lichens.

\section{Discussion}

While the local bedrock is nominally acidic, near the trimlines, many lichens, mosses, and vascular plants indicate basic or circumneutral soil conditions. Some examples are, amongst the lichens - Xanthoria elegans, Physcia caesia, Dermatocarpon reticulatum, and Placidium squamulosum (Vitt et al. 1988); and mosses - Thuidium abietinum, Tortula ruralis, Rhytidium rugosum, and Encalypta sp. (Ireland 1982). Amongst the neutral to basic soil indicators in the vascular plants, Picea glauca dominates the forests near the trimlines.

There is no clear reason for the commonness of calciphiles on nominally acidic bedrock. We observed "dust" on rocks and saxicolous plants in the area which may be calcareous loess deposited on the outcrops rocks when nearby mudflats dry and are exposed to wind. In other situations, wave splash and wind-driven spray may wet the surfaces with delta water. Delta surface water is nutrient-rich and alkaline (Hall et al. $2003 *$; e.g., mean $\mathrm{pH}$ of lakes $=8.2$, of rivers $=8.0$ ). We found no data on the $\mathrm{pH}$ of local rainfall.

At many sites, the most abundant lichen below the trimline was Physcia caesia (a nitrophile; McCune and Geiser 1997; Brodo et al. 2001). Physcia caesia, Xanthoparmelia somloënsis, and Staurothele fissa were common pioneer species in both perched basins and open sites whereas Phaeophyscia sciastra colonized only perched basins. Primary sites for colonization were cracks; seepage, rough, and protected shady/moist surfaces; and dark-colored mineral bands. As birds often rest on shore-side rocks, nitrogenous bird waste may play a role in both colonization and species composition of the saxicolous communities.

Wide variations in water level, and ice-scour, along the rivers and Lake Athabasca may lead to the indistinct and wavy trimlines characteristic of open and some semi-restricted sites. At many sites, below the trimline there was a light-colored rock band situated above a reddish-orange band of oxidized iron (e.g., Figure $2 \mathrm{c}, \mathrm{h}$ ). This color pattern may indicate a transition from frequent reduction and oxidation due to water level fluctuations (reddish-orange) to infrequent inundation (light colored rock). Ice scour by wind- or river-driven ice blocks may scrape the rocks free of lichens, especially foliose species that are not appressed to the rock. The chaotic piling of ice blocks characteristic of break-up might contribute to the irregularity of the trimlines on open drainage sites. Flaking of the bedrock, perhaps by ice-blocks pulling away from the rock, or by in situ formation of ice lenses, might also act to delay lichen succession.

Width of the trimline, slope, aspect, and basin type were not related to the number of species found below the trimline (Marsh and Timoney 2003*). While site factors such as aspect can be important in determining the distribution and performance of lichens (Beckelhimer and Weaks 1986; Eversman 1982), both the relatively short time for establishment and the humidity along the shores may have masked physical effects.

Gregory (1976) found double trimlines along a river in Australia. We found no double trimlines (indicative of a high flood, followed by a period of lichen establishment below the trimline, followed by a lower flood that results in a second, lower trimline). Fourteen of 16 trimline elevations fell within a narrow range of 210.26-210.92 $\mathrm{m}$ asl. Based on lichen thalli diameters and local growth rates, Timoney and Marsh (2004) surmised that most of the trimlines probably formed during the period 1976 to 1990 . Many of the trimlines probably formed during relatively-persistent high water which followed a major 1974 ice-jam flood. The drought-prone early 1980s may have been a key time of lichen establishment below trimlines (Marsh and Timoney 2003*). The lichen data bear on the controversy surrounding the history of changing water levels in the Peace-Athabasca Delta. As the trimlines established in response to flooding that occurred after the construction of the Bennett Dam, the trimlines cannot be construed as pre-dam high water marks. The reverse is true - they are post-dam high water marks.

How long might trimlines persist in the absence of a subsequent rise in water level that would obliterate colonizing lichens? Thalli below trimlines might reach a mean diameter within one standard deviation of 
above-trimline diameters in about 27 to 55 years of uninterrupted growth. Allowing for a lichen establishment lag time of about 6-10 years in the delta (Marsh and Timoney $2003^{*}$ ), trimlines there might remain visually distinct for roughly $33-65$ years.

Some sites had no datable lichens (only Staurothele) below the trimline. Species differences in colonization rates (Gilbert and Giavarini 2000) of these relatively recent surfaces, differences in susceptibility to disturbance, and site influences on lichen establishment and survival might be involved in the absence of many species below trimlines. As sites that offer insight into lichen colonization, succession, lichenometry, water level variations, and disturbance ecology, lichen trimlines deserve more study.

\section{Acknowledgments}

Thanks to Irwin Brodo, James Case, Alan Fryday, D. J. Hill, Derek Johnson, Anne Robinson, Roger Rosentreter, Mark Seaward, and Pat Wolseley for their comments regarding lichen zonation/trimlines, lichenometry, and lichen susceptibility to immersion. BC Hydro and Wood Buffalo National Park Fort Chipewyan staff provided logistic support. Stephen Hamilton assisted with office tasks.

Documents Cited (marked $*$ in text)

Esslinger, T. L. 1997. A cumulative checklist for the lichenforming, lichenicolous and allied fungi of the continental United States and Canada [online]. North Dakota State University. Available from: http://www.ndsu.nodak.edu/ instruct/esslinge/chcklst/chcklst7.htm. [updated 17 July 2002; cited 4 February 2004]

Hall, R., B. Wolfe, and T. Edwards. 2003. A multi-century flood, climatic, and ecological history of the Peace-Athabasca Delta, northern Alberta, Canada. Final report to BC Hydro, Burnaby, British Columbia.

Marsh, J., and K. Timoney. 2003. Saxicolous lichen trimlines in the Peace-Athabasca Delta of Northern Alberta: flora, growth rates, establishment and persistence, and history of water levels. Final report to BC Hydro, Burnaby, British Columbia.

Timoney, K. P. 2004. Vegetation, climate, and biophysical variation and change in the Peace-Athabasca Delta, 19932003. Final report to BC Hydro, Burnaby, British Columbia.

\section{Literature Cited}

Beckelhimer, S. L., and T. E. Weaks. 1984. The effects of periodic inundation and sedimentation on lichens occurring on Acer saccharinum L. The Bryologist 87: 193-196.

Beckelhimer, S. L., and T. E. Weaks. 1986. Effects of watertransported sediment on corticolous lichen communities. The Lichenologist 18: 339-347.

Brodo, I. M., S. D. Sharnoff, and S. Sharnoff. 2001. Lichens of North America. Yale University Press, New Haven, Connecticut.
Eversman, S. 1982. Epiphytic lichens of a ponderosa pine forest in southeastern Montana. The Bryologist 85: 204213.

Gilbert, O. L., and V. J. Giavarini. 1997. The lichen vegetation of acid watercourses in England. The Lichenologist 29: 347-367.

Gilbert, O., and V. Giavarini. 2000. The lichen vegetation of lake margins in Britain. The Lichenologist 32: 365-386.

Gregory, K. J. 1976. Bankfull identification and lichenometry. Search 7: 99-100.

Hale, M. E. 1984. The lichen line and high water levels in a freshwater stream in Florida. The Bryologist 87: 261-265.

Ireland, R. R. 1982. Moss flora of the Maritime Provinces. National Museums of Canada. Publications in Botany 13. Ottawa, Ontario.

McCune, B., and L. Geiser. 1997. Macrolichens of the Pacific Northwest. Oregon State University Press, Corvallis, Oregon.

Mitchell, J. G. 2002. Down the drain? The incredible shrinking Great Lakes. National Geographic, September: 34-51.

Moss, E. H. 1983. Flora of Alberta. Second edition. University of Toronto Press, Toronto, Ontario.

National Wetlands Working Group. 1988. Wetlands of Canada. Environment Canada. Ecological Land Classification Series, Number 24. Ottawa, Ontario.

Pereira, I., M. Casares, and X. Llimona. 1987. Aportacion al conocimiento de los liquenes hidrofilos de Sierra Nevada (Granada, S. de España). Cryptogamie, Bryologie, et Lichenologie 8: 263-273.

Ried, A. 1974. Metabolism and frequency distribution limits of lichens. II. Water utilization and assimilation patterns of crustaceous lichens in adjacent locations and their resistance to drought and submersion. Technical Translation 1774. National Research Council of Canada, Ottawa, Ontario.

Rosentreter, R. 1984. The zonation of mosses and lichens along the Salmon River in Idaho. Northwest Science 58: 108-117.

Santesson, R. 1939. Über die Zonationsverhältnisse der lakustrinen Flechten einiger Seen im Anebodagebiet. Meddelanden från Lunds Universitets Limnologiska Institution 1: $1-70$.

Scott, G. D. 1967. Studies of the lichen symbiosis: 3. The water relations of lichens on granite kopjes in Central Africa. The Lichenologist 3: 368-385.

Timoney, K. P. 2002. A dying delta? A case study of a wetland paradigm. Wetlands 22: 282-300.

Timoney, K. P., and J. E. Marsh. 2004. Lichen trimlines in northern Alberta: establishment, growth rates, and historic water levels. The Bryologist 107: 429-440.

Vitt, D. H., J. E. Marsh, and R. B. Bovey. 1988. Mosses, lichens \& ferns of northwest North America. Lone Pine Publishing. Edmonton, Alberta.

Winchester, V., and S. Harrison. 2000. Dendrochronology and lichenometry: colonization, growth rates and dating of geomorphological events on the east side of the North Patagonia Icefield, Chile. Geomorphology 34: 181-194.

Received 12 May 2004

Accepted 4 March 2005 